\title{
Posterior Urethral Valves Type 3
}

National Cancer Institute

\section{Source}

National Cancer Institute. Posterior Urethral Valves Type 3. NCI Thesaurus. Code C123211.

A posterior urethral valve, presumed to result from incomplete canalization of the urethra, that is located immediately distal to the vera montanum. 